\title{
Correlation between Emotional Intelligence and Creative Behaviour of Primary School Teachers
}

\begin{abstract}
There is a certain amount of research that proves that positive emotions and mood play an important role in creative human activity (Abele-Brehm, 1992; Tokarz, 2011; Kunat, 2015). Particularly valuable is ability to recognise emotions and communicate them. It is also important to accept experienced emotions, gain a skill to react accordingly as well as ability to evoke and regulate emotions. According to Salovey and Mayer's model, the aforementioned dispositions are elements of emotional intelligence. It turns out that emotional intelligence can stimulate creative activity since it enables management of emotional expenditure (Nęcka, 2001).

The paper presents results of research conducted among teachers of primary schools. It was assumed that there is a correlation between emotional intelligence and creative activity of teachers. The research can contribute to development of emotional skills of teachers and to intensify their creative activity. That, in turn, can translate into shaping of innovative school environment that fits the needs of contemporary young person - a student.
\end{abstract}

Keywords:

emotional intelligence, creative behaviours, teacher, primary school

\section{THE CONCEPT OF EMOTIONAL INTELLIGENCE}

Early concepts of intelligence were characterised by a national approach. Emotions, as a key factor in specific situations, were not seen as intelligence at work

1 Faculty of Education, University of Białystok, Poland.

E-MAIL: k.szorc@uwb.edu.pl ORCID: 0000-0002-8911-6979 
- on the contrary, it was considered that reason and passion are opposites. Emotions were blamed for a total lack of brain control. For this reason, traditional, cognitive oriented psychology has a rather controversial view on emotional intelligence (Maruszewski \& Ścigała, 1998a).

The most common models of intelligence in scientific papers are an ability model of Mayer and Salovey (Salovey \& Mayer 1990), or Bar-On (Bar-On, 1997; Bar-On, 2001).

The first concept of Salovey and Mayer presumed that emotional intelligence is a subgroup of social intelligence and was defined as an ability to trace own emotions as well as those of others, to differentiate them and utilise this information to direct thinking and acting.

Though initially the authors of this theory associated emotional intelligence with certain personality traits, in the process of evolution of this concept they focused entirely on cognitive abilities. The researchers clearly separated emotional intelligence from social intelligence. Eventually emotional intelligence dimension was defined as

"an ability of proper perception, evaluation and expression of emotions, an ability to access emotions, an ability to generate them in the moments when they could support thinking, an ability to understand emotions and understand emotional knowledge and an ability to regulate emotions in such a way that supports emotional and intellectual development” (Salovey \& Sluyter, 1999, p. 34).

In the structure of emotional intelligence, then, Salovey and Mayer originally singled out three (Salovey \& Mayer, 1990, pp. 185-211) and then four component groups.

This modified model of Salovey and Mayer includes the following ability groups:

- Perceptions, considering and expressing of emotions,

- Emotional support of thought process,

- Understanding, analysis of emotions and utilising of emotional knowledge,

- Reflective regulations of emotions in order to support emotional and intellectual development.

It is important to notice that the presented model, despite the fact that it lists ability groups that constitute emotional intelligence, points to development as well. The specific components are in hierarchical order where at the lowest level are the basic abilities of perception and expression of emotions. The highest level is asso- 
ciated with reflection and conscious regulations of emotion that favours personal understanding and development.

The concept of emotional intelligence points to the fact that acquiring emotional skills spreads in time and continues throughout the whole life. In turn, reaching each skill built into elements of emotional intelligence model requires constant involvement and effort of a person. It seem, however, that people with high emotional intelligence are quicker to go through the stages and to acquire abilities and are able to master more of them.

It is also worth noticing that despite a number of doubts (proven by empirical data) of other researchers as to uniformity of presented concept (Day \& Carroll, 2004; Mayer et al., 2003; Ciarrochi, Chan, \& Caputi, 2000), this is probably the only model that at present can be called intelligence. There are following criteria that support this:

- possibility to make particular components, understood as abilities, operational;

- met correlation criterion with a standard measured intelligence;

- intelligence level increase due to age (Mayer, Perkins, \& Salovey, 2001; Mayer, Salovey, \& Caruso, 2000).

This paper places research in a context of the ability model of Mayer and Salovey (Salovey \& Mayer, 1990). It was assumed that emotional intelligence is "a set of abilities enabling use of emotions in solving problems, especially in social situations” (Jaworowska \& Matczak, 2001, p. 5).

\section{THEORETICAL BASIS OF CREATIVE BEHAVIOUR}

In the context of the undertaken issue it is important to define the term "creativity". I will start with a definition of Nęcka, a polish classic of research on creativity, who claims that creativity can be seen as a feature of a product in which "there is a conjunction of two features: novelty and value” (Nęcka, 2005). Both novelty and value raise a number of problems when it comes to determine what is or can possibly be creative. It turns out that both novelty and values are relative features that depend on context, be it cultural, social, or political (Nęcka, 2005).

The solution to the above problem could be an approach suggested by Cropley (2001), who defines creativity in terms of paradoxes. On the one hand, creativity assumes bringing something novel but rooted in something that already exists. On 
the other hand, it is required to move away from social standards and breach of them but in such a way that society could accept it.

Social acceptation of a product or work is also a necessary element of creativity according to Karwowski (Karwowski \& Gajda, 2010). The author emphasises that it is also about recognition of specialists, authorities in a given field, not the masses. Thus, creativity is perceived as elite phenomena (Karwowski \& Gajda, 2010). So, "creativity is calling to life products that carry value - though this element is present in every definition, although, sometimes it is replaced by utility or usefulness, in fact it is definitely determined by originality factor. Not rightly so, since the ideas and behaviours which are original and useless have their place in Guinness Book of Records but not in the annals of culture” (Karwowski \& Gajda, 2010, p. 13).

Karwowski (Karwowski \& Gajda, 2010) points also to a fact, often underestimated or omitted, that creativity should not be mistaken with being creative. Yes, these concepts have similar meaning but are not identical. The differences are mainly about the fact that being creative describes a person but creativity refers to a product. Being creative could refer to a creative potential, a feature of a person. The author emphasises that "creativity is an effect of interaction of personality traits of a single person who under influence of environment undertakes creative attempts and efforts" (Karwowski \& Gajda, 2010, p. 14).

Moving away from deeper analysis of various attempts to define the essence of creativity it is worthwhile to mention basic properties of creativity as an object of psychological research. From that perspective creativity is expressed with the following features:

- $\quad$ matter is transformed (direction of changes is known);

- a certain goal is known, an ideal outcome;

- $\quad$ the process can be consciously understood;

- material can be virtually everything;

- the effect can be totally different from the expected and desired, can realise different values, bring about a new value, can break assumptions and vital attitude of the initial question, goal or intention (Nęcka, 2005).

Creativity from the psychological standpoint - both elitist and egalitarian - requires a combination of internally contradictive personal characteristics; it is a result of contradictive types of motivation: various goals, mechanisms in different times. An intensive motivation is necessary but task oriented attitude does not require creative effectiveness. 
To sum up, it can be said that creativity of a human being is a multidimensional construct and manifests in such features as: curiosity, tinkering, tolerance of ambiguity, originality, focus on a task, seizing of an opportunity, and expression of one's thoughts and emotions. Fromm formulated creativity in a poetic way when he wrote that ability to create is being ready to be born again each day (after: Szmidt, 1997).

\section{CONCEPTS OF CREATIVE BEHAVIOURS AND THEIR CONDITIONING}

According to a common concept that have dominated the subject literature, creative human behaviour (creativity as process) or the effects of these behaviours (creativity as a product) are defined by two attributes: novelty and widely understood usefulness (value) (Nęcka, 2001). Averill (2000) adds the third criteria which is authenticity, meaning that creative activity and creative works grow out of an individual ego. Even though creative activity is essentially determined by situational factors, environment and culture, it is, most of all, determined by personal characteristics; people differ as to frequency with which they undertake creative activities and as to the quality of its outcome, i.e., the degree of novelty and usefulness.

Personal disposition which enables a person for creativity is at times called "being creative". This disposition is of a complex nature (Nęcka, 2001) since it covers both intellectual abilities and various features of cognitive functions (i.e., fluidity and flexibility of thinking and imaginative abilities) as well as personal traits (i.e., openness for experience, non-conformity and perseverance). Scholars, despite of a lot of research, do not agree whether there is and if so what is a connection between creativity and traditionally understood "academic" intelligence (see: Karwowski, 2005; Matczak, Jaworowska, \& Stańczak, 2000; Nęcka, 2001).

The concept of Popek (2008), leading researcher of human creative behaviours, is based on the assumption that creative attitude consist of two main areas: cognitive and character. The cognitive area is associated with intellectual disposition; it is widely understood, though, than it takes place with IQ measures. This area includes heuristic behaviour defined by features such as independent observation, logical memory, creative imagination, intellectual flexibility, reflectiveness. The opposite of heuristic behaviour is algorithmic behaviour that is characterised by copying and reproduction. The second area, referring to character, deals with potential cognitive capabilities of a human individual. The author, additionally, assumes superiority of personality in relation to abilities and special talents and also assumes that effective realisation of cognitive predispositions is possible only 
in cooperation with other personality traits. These traits Popek describes as conformism and non-conformism. Conformism refers to being dependent, non-flexibility to adapt, stereotypical attitude, and low self-esteem. Non-conformism is described by opposite features like being independent, self-sufficient, originality, resiliency, and high self-esteem.

Obviously, creative behaviour benefits from heuristic behaviour and nonconformism while reproductive attitude is characterised by algorithmic behaviour and conformism (Figure 1).

Figure 1. Model of Creative Attitude in Learning and Action

\begin{tabular}{|c|c|c|c|}
\hline \multirow{4}{*}{ Re-creative attitude } & \multicolumn{2}{|c|}{ Characterological area factors } & \multirow{4}{*}{ Creative attitude } \\
\hline & Conformism (K) & Non-conformism (N) & \\
\hline & $\begin{array}{l}\text { Algorithmic } \\
\text { behaviour }(A)\end{array}$ & $\begin{array}{c}\text { Heuristic } \\
\text { behaviour }(\mathrm{H})\end{array}$ & \\
\hline & \multicolumn{2}{|c|}{ Cognitive area factors } & \\
\hline
\end{tabular}

Source: KANH - Creative Behaviour Questionnaire (Popek, 1989, p. 17).

\section{CONNECTION BETWEEN EMOTIONAL INTELLIGENCE AND CREATIVE BEHAVIOURS - RESEARCH STATUS}

A number of researchers are pondering whether one of the features that enable creativity and which can predict a success in this area is emotional intelligence. Data concerning the connection between creative behaviour and emotion can provide proofs and premises to formulate hypothesis.

The ancient philosophers argued that there was a close connection between creativity and emotions (Matczak \& Knopp, 2013). Now, both common views of lay people and scientific literature seem to hold the same standpoint. The words of Seneca calling upon Aristotle about an element of madness that is present in every creative genius are often quoted (after: Matczak \& Knopp, 2013). The results of research that aims to verify this concept are far from unanimous. There is a lot of data that proves the role of positive emotions and positive mood, often described as a combination of low level energetic excitation and high hedonistic tone as factors that favour creativity and especially divergent thinking that is considered to be the base of creativity (Abele-Brehm, 1992; Kocowski \& Tokarz, 1991; Kolańczyk, 1999; Kolańczyk \& Świerzyński, 1995).

It is difficult to find empirical data that would directly prove the connection between emotional intelligence and creative abilities, attitudes, or achieve- 
ments. Indirect connection can be proved by research into connection between creativity and alexithymia, i.e., difficulty in verbalising one's emotions. It turns out that alexithymia is closely related with emotional intelligence. Moreover, it is significant that there is negative connection between alexithymia and creativity (Matczak \& Knopp, 2013, p. 124).

A research conducted by Czernecka and Szymura (2008) correlated alexithymia with creative abilities. Alexithymia was assessed with questionnaire ALEX-40 (see: Maruszewski \& Ścigała, 1998a) and creative abilities were measured with a task that required to construct new object using geometrical shapes and a creative thought test of Urban \& Jellen. It turned out that in both cases there were slight but significant correlations that presented lower creative abilities among people with alexithymia.

An important prerogative to perform own research was a research conducted by Karwowski (2004). The author focused on finding connections between academic intelligence, emotional intelligence and creative abilities of high school students with various school results. In case of male students, there were no significant correlation between school results and creative abilities and emotional intelligence. In case of female students, this correlation was of a slightly different character. There were correlations between school results and creative abilities. The correlation between emotional intelligence and school results was not found, however. The research also sought to find a correlation between emotional intelligence and creative abilities of high school students. This correlation proved to be statistically insignificant. There was, however, significant correlation between academic intelligence and creative abilities. What is interesting, the results of research show that all three variables ("academic" intelligence, emotional intelligence, and creative abilities) are positively correlated with school results.

The above analysis can indirectly point to the fact that there is correlation between emotional intelligence and creative behaviours of a human being. It is worthwhile, then, to attempt an analyse whether and how much this correlation applies to the teachers of primary schools.

\section{METHODOLOGICAL PREMISES}

The main goal of the research was to show a correlation between emotional intelligence of primary school teachers and their creative behaviour. The following research questions were formulated. 


\section{MAIN QUESTION:}

Is there a correlation between emotional intelligence and creative behaviour of primary school teachers?

\section{SPECIFIC QUESTIONS:}

1. Is there a correlation between emotional intelligence and conformism?

2. Is there a correlation between emotional intelligence and algorithmic behaviours?

3. Is there a correlation between emotional intelligence and non-conformism?

4. Is there a correlation between emotional intelligence and heuristic behaviours?

The analysis of research literature into emotional intelligence and creativity allows for proposing the following hypothesis. They are the answer to the above research questions and are hypotheses concerning the existence and the strength of correlations between variables.

\section{THE MAIN HYPOTHESIS:}

There is a correlation between emotional intelligence and creative attitudes of primary school teachers.

\section{SPECIFIC HYPOTHESES:}

1. People with high level of emotional intelligence display low level of conformist attitudes.

2. People with high level of emotional intelligence display low level of algorithmic behaviours.

3. Teachers with high level of emotional intelligence display higher level of nonconformist behaviours.

4. Teachers with high level of emotional intelligence display higher level of heuristic behaviours.

The research employed correlative research model. Two tools were used:

- Emotional Intelligence Questionnaire INTE,

- Creative Behaviour Questionnaire KANH.

Emotional Intelligence Questionnaire INTE of N.S. Schutte, J.M. Malouff, L.E. Hall, D.J. Haggerty, J.T. Cooper, Ch.J. Golden, \& L. Dornheim - in the polish version adapted by A. Ciechanowicz, A. Jaworowska, \& A. Matczak (Jaworska \& Matczak, 2001) was used to measure emotional intelligence understood as an abil- 
ity to recognise, understand and control own emotions as well as those of others and also an ability to effectively use emotions in directing own actions and those of others (according to P. Salovey and J. Mayer's concept). This questionnaire was used in research into emotional intelligence of primary school teachers.

Creative Behaviour Questionnaire KANH of Stanisław Popek is used to research creative abilities understood as personal properties of a person (creative attitude). The questionnaire assumes that creative attitude consist mainly of two areas: cognitive and characterological. Cognitive area refers to intellectual dispositions whereas characterological refers to potential cognitive abilities of a person.

From among intellectual dispositions there were singled out heuristic behaviour and the opposite - algorithmic behaviour. Heuristic behaviour $(\mathrm{H})$ was described by features such as: autonomy of observation, logical memory, creative imagination, divergent thinking, reconstructive and autonomous learning, learning through reason, intellectual flexibility, cognitive activity, reflectiveness, intellectual autonomy, constructive creativity, verbal creativity, and potential abilities for creativeness.

Algorithmic behaviour (A) was described as: controlled perceptivity, mechanical memory, re-creative imagination, convergent thinking, re-productive learning, intellectual rigidity, cognitive passivity, low level of reflectivity, lack of technical and artistic ingenuity, low skill in processing and construction.

A set of characterological features was expressed in the questionnaire in the conformist and non-conformist attitude. Conformism (K) was described by the following features: dependency, passivity, adaptive rigidity, stereotypical approach, submission, timidity, weakness, lack of independence, lack of internal organisation, being defensive, compliance, irresponsibility, low resiliency and perseverance, lack of criticism, intolerance, and low self-esteem.

Non-conformism (N) was described as a set of opposite features: being independent, being active, adaptive flexibility, being original, being consistent, courage, self-reliance, being organised, being spontaneous, openness, being expressive, resilience, endurance, responsibility, self-criticism, tolerance, high self-esteem.

\section{CHARACTERISTIC OF A RESEARCH GROUP}

On-target and random selection parameter was used to establish a research group. 55 of randomly chosen primary school teachers from Podlaskie province took part in the research. 
Table 1. Structure of Research Sample (According to Independent Variables)

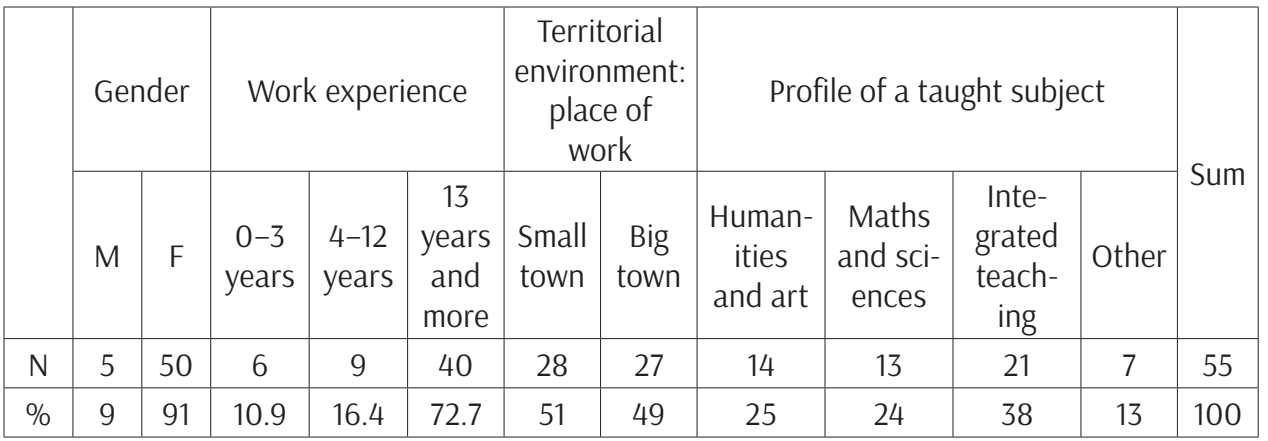

Source: author's own research.

The respondents represented the town of Białystok, towns of Białystok County and of Mońki County. The research was conducted in 2018.

\section{RESULTS OF THE RESEARCH}

The first stage of statistical analysis was to check consistency of researched variable spread with a normal spread. The results of analysis allowed to choose adequate tests for data analysis.

It is noticeable that the measures of central tendency (average, median, dominant) are very similar and the standard deviation is relatively low (except INTE) which means that the answers were focused around the average and that the fringe values did not affect it.

Table 2. Descriptive Statistics - INTE and KANH

\begin{tabular}{|c|c|c|c|c|c|}
\hline Values & Sum INTE & Sum of H scale & Sum of N scale & Sum of K scale & Sum of A scale \\
\hline Average & 132.1818 & 20.2075 & 19.8679 & 11.9796 & 15.4231 \\
\hline Mediana & 132.0000 & 20.0000 & 19.0000 & 11.0000 & 15.0000 \\
\hline Dominant & 127.00 & 19.00 & $17.00 \mathrm{a}$ & $8.00 \mathrm{a}$ & 16.00 \\
\hline $\begin{array}{c}\text { Standard } \\
\text { deviation }\end{array}$ & 12.48717 & 3.55375 & 3.36862 & 4.84549 & 4.10330 \\
\hline
\end{tabular}

a - there is a number of modal values; the smallest value was given

Source: author's own research. 
Coefficient of Cronbach's Alpha was calculated for the gathered data to confirm reliability of scale data and specifically to confirm how much the answers were consistent within the limits of specific scales.

Table 3. Reliability Statistics

\begin{tabular}{|c|c|c|c|c|}
\hline $\begin{array}{c}\text { Cronbach's } \\
\text { Alpha } \\
\text { INTE }\end{array}$ & $\begin{array}{c}\text { Cronbach's } \\
\text { Alpha } \\
\text { Scale H }\end{array}$ & $\begin{array}{c}\text { Cronbach's } \\
\text { Alpha } \\
\text { Scale N }\end{array}$ & $\begin{array}{c}\text { Cronbach's } \\
\text { Alpha } \\
\text { Scale K }\end{array}$ & $\begin{array}{c}\text { Cronbach's } \\
\text { Alpha } \\
\text { Scale A }\end{array}$ \\
\hline 0.894 & 0.567 & 0.550 & 0.785 & 0.674 \\
\hline
\end{tabular}

Source: author's own research.

As the data in Table 3 points out, the biggest reliability of the research was in INTE scale and K (conformism) scale, as well as in A (algorithmic behaviour) scale. The lowest reliability was registered in the scale $\mathrm{H}$ (heuristic scale) and scale $\mathrm{N}$ (non-conformism).

\section{CORRELATION BETWEEN EMOTIONAL INTELLIGENCE (INTE) OF PRIMARY SCHOOL TEACHERS AND SPECIFIC SCALES OF THE KANH QUESTIONNAIRE}

In order to show correlation between emotional intelligence of primary school teachers and their creative behaviour, a linear r-Pearson correlation coefficient was calculated. The correlation between INTE variables and specific KANH scales ( $\mathrm{K}$ - conformism, $\mathrm{A}$ - algorithmic behaviours, $\mathrm{N}$ - non-conformism, $\mathrm{H}$ - heuristic behaviours) was also sought.

All analysis were done using SPSS programme. The hypotheses were verified on salience level of 0.01 and 0.05 .

Analysis of research results proved the existence of statistically valid correlation between emotional intelligence and heuristic behaviours and non-conformism (Table 4).

The research result also proved that the level of emotional intelligence positively correlates with heuristic behaviour and non-conformism. The correlation between INTE and H scale (heuristic behaviours) was $r=0.376$ with $p<0.01$. The correlation between INTE and N scale (non-conformist behaviours) was $r=0.364$ with $\mathrm{p}<0.01$. 
Table 4. Correlation between INTE and KANH (Coefficient of Pearson's Linear Correlation)

\begin{tabular}{|c|c|c|c|c|c|}
\hline \multicolumn{2}{|c|}{} & \multicolumn{4}{|c|}{ Creative behaviours (KANH) } \\
\cline { 3 - 6 } \multicolumn{2}{|c|}{} & H scale & N scale & K scale & A scale \\
\hline \multirow{2}{*}{ INTE } & $r$ & $.376^{* *}$ & $.364^{*}$ & -0.276 & 0.004 \\
\cline { 2 - 6 } & $p$ & 0.006 & 0.007 & 0.055 & 0.980 \\
\hline
\end{tabular}

* - key correlation at the level of 0.05 (bilateral); ${ }^{* *}$ - key correlation at the level of 0.01 (bilateral) Source: author's own research.

The research does not show a statistically significant correlation between emotional intelligence of primary school teachers and conformist and algorithmic behaviours. The correlation between emotional intelligence and K scale (conformism) has a negative direction and was $r=-0.276$ and correlation coefficient between emotional intelligence and A scale (algorithmic behaviour) was $\mathrm{r}=0.004$.

The analysis of gathered material shows that there is statistically significant positive correlation between emotional intelligence of researched primary school teachers and their creative attitudes. It is proven by the correlation between emotional intelligence measure with INTE Questionnaire and $\mathrm{H}$ and $\mathrm{N}$ scales of KANH Creative Behaviour Questionnaire.

\section{SUMMARY AND CONCLUSIONS}

The last decades have been affluent in research into emotional intelligence and predispositions and creative behaviours of humans. Researchers from a social science field (psychology, pedagogy, and economics) wonder whether emotional intelligence is a trait that predisposes creativity. The answers to the above issue should be sought in research into correlation between creative behaviours and emotions.

Because analysis of available literature does not show direct correlations (or the lack of such), the undertaken research focused on correlation between emotional intelligence and creative behaviours of primary school teachers. 55 teachers were researched where majority of them were women $(n=50)$. Almost $75 \%$ of them have been working at school for over 13 years. Almost equal numbers works in a big town (49\%) and small towns (51\%). The biggest group was that of teachers of integrated teaching (38\%).

The results of the research allowed to formulate the following conclusions: 
- Research did not confirm the first hypothesis. There was no correlation between the level of emotional intelligence and conformist attitudes.

- The second hypothesis was not confirmed, either. The results do not corroborate that there is a correlation between emotional intelligence and algorithmic behaviours of the primary school teachers.

- The research confirmed the third hypothesis that there is a correlation between emotional intelligence and non-conformist behaviours.

- The fourth hypothesis was also confirmed. The research proved that there is a correlation between the level of emotional intelligence and heuristic attitudes. Besides, in cases of both $\mathrm{H}$ scale (heuristic behaviours) and $\mathrm{N}$ scale (non-conformist) there was the lowest reliability of the results.

As Matczak emphasises, the growing dynamics of conditions of a contemporary teacher life and of tasks put in front of them creates a situation that trying to change is not enough. What is required is to anticipate the changes (Matczak \& Knopp, 2013). Features that up till now belonged to very active people today are a must for everybody who wants to exists in a work market and constructively solve problems. It turns out that "ability to rationally, logically think that was a part of traditionally understood intelligence, is not considered any more as sufficient to explain and predict effectiveness and success in life. There is a need for other concepts of explanation and other potential predictors” (Matczak \& Knopp, 2013, p. 14). Emotional intelligence can be, without a doubt, included into these predictors as well as creative behaviours of individuals.

The undertaken research pointed to correlation between emotional intelligence and creative attitudes of primary school teachers. The special role of primary school teacher should be emphasised due to the fact that they work with students with the most "flexible" personality where the qualifications can be diagnosed and awoken or cause that even "inborn" talents would be lost forever. This would be a good place to call upon wide research of Uszyńska-Jarmoc where the author observed that school destroys individual personality of a child (especially at an early school age) and their creative potential (Uszyńska-Jarmoc, 2007).

Moreover, there is a need to develop creativity in cognitive area as well as in cognitive-motivational and performance area. There should be generated simulations that call for creative thinking (fluidity, flexibility, novelty). It is essential to stimulate divergent thinking among teachers and develop their ability to come up with a number of solutions and ideas. In the process of training of teachers it is of paramount importance to develop openness for new ideas and experiences, stimu- 
lation of cognitive curiosity and willingness for experimentation and readiness for undertaking new tasks and professional challenges.

The limitations of the research of this paper were a small research sample, a bigger percentage of people with a longer work experience and a lack of teachers working in rural areas. The future research, then, should consider a bigger sample taking into consideration teachers' work experience, work place (territorial environment) and an even spread concerning gender. It would be advisable to include teachers working on other level of education - high schools and kindergartens. Moreover, in further research it would be useful to focus on conditioning of emotional intelligence and creative behaviour. It also seems interesting to search for stimulants and inhibitors both of creative attitudes and emotional skills.

\section{References}

Abele-Brehm, A. (1992). Positive and Negative Mood Influences on Creativity: Evidence for Asymmetrical Effects. Polish Psychological Bulletin, 23(3), pp. 203-221.

Averill, J.R. (2000). Intelligence, Emotion, and Creativity: From Trichotomy to Trinity. In: R. Bar-On, \& J.D.A. Parker (Eds.), The Handbook of Emotional Intelligence: Theory, Development, Assessment, and Application at Home, School, and in the Workplace (pp. 277-298). San Francisco: Jossey-Bass.

Bar-On, R. (1997). EQ-i: BarOn Emotional Quotient Inventory. A Measure of Emotional Intelligence. User's Manual. Toronto: Multi-Health System.

Bar-On, R. (2001). Emotional Intelligence and Self-Actualization. In: J. Ciarrochi, J.P. Forgas, \& J.D. Mayer (Eds.), Emotional Intelligence in Everyday Life: A Scientific Inquiry (pp. 82-97). Philadelphia, PA: Psychology Press.

Ciarrochi, J.V., Chan, A.Y.C., \& Caputi, P. (2000). A Critical Evaluation of the Emotional Intelligence Construct. Personality and Individual Differences, 28(3), pp. 539-561. DOI: 10.1016/S0191-8869(99)00119-1.

Cropley, A.J. (2001). Creativity in Education \& Learning: A Guide for Teachers and Educators. New York: Routledge.

Czernecka, K., \& Szymura, B. (2008). Alexithymia - Imagination - Creativity. Personality and Individual Differences, 45(6), pp. 445-450. DOI: 10.1016/j.paid.2008.05.019.

Day, A.L., \& Carroll, S.A. (2004). Using an Ability-based Measure of Emotional Intelligence to Predict Individual Performance, Group Performance, and Group Citizenship Behaviours. Personality and Individual Differences, 36(6), pp. 1443-1458. DOI: 10.1016/S01918869(03)00240-X.

Goleman, D. (1997). Inteligencja emocjonalna. Poznań: Media Rodzina.

Goleman, D. (1999). Inteligencja emocjonalna w praktyce. Poznań: Media Rodzina.

Jaworowska, A., \& Matczak, A. (2001). Kwestionariusz Inteligencji Emocjonalnej INTE: N.S. Schutte, J.M. Malouffa, L.E. Hall, D.J. Haggerty'ego, J.T. Cooper, C.J. Goldena, L. Dornheim. Podręcznik. Warszawa: Pracownia Testów Psychologicznych Polskiego Towarzystwa Psychologicznego. 
Karwowski, M. (2004). Dzieci twórcze czy konformistyczne? Wartości wychowawcze Polaków 1992-2002. Ruch Pedagogiczny, 3-4, pp. 24-44.

Karwowski, M. (2005). Konstelacje zdolności. Typy inteligencji a kreatywność. Kraków: Oficyna Wydawnicza Impuls.

Karwowski, M. (2009a). Klimat dla kreatywności. Koncepcje, metody, badania. Warszawa: Centrum Doradztwa i Informacji Difin.

Karwowski, M. (2009b). Zgłębianie kreatywności. Studia nad pomiarem poziomu i stylu twórczości. Warszawa: Wydawnictwo Akademii Pedagogiki Specjalnej.

Karwowski, M., \& Gajda, A. (Eds.) (2010). Kreatywność (nie tylko) w klasie szkolnej. Warszawa: Wydawnictwo Akademii Pedagogiki Specjalnej.

Kocowski, T., \& Tokarz, A. (1991). Prokreatywne i antykreatywne mechanizmy motywacji aktywności twórczej. In: A. Tokarz (Ed.), Stymulatory i inhibitory aktywności twórczej (pp. 79-95). Kraków: Instytut Psychologii UJ .

Kolańczyk, A. (1999). Czuję, myślę, jestem. Świadomość i procesy psychiczne w ujęciu poznawczym. Gdańsk: GWP.

Kolańczyk, A., \& Świerzyński, R. (1995). Emocjonalne wyznaczniki stylu i plastyczności myślenia. Przeglq̨d Psychologiczny, 38(3/4), pp. 279-304.

Kunat, B. (2015). Pasja jako źródło twórczości codziennej człowieka. In: J. Uszyńska-Jarmoc, \& B. Kunat (Eds.), Twórczość codzienna jako aktywność całożyciowa człowieka (pp. 94-103). Białystok: Trans Humana.

Maruszewski, T., \& Ścigała, E. (1998a). Emocje - aleksytymia - poznanie. Poznań: Wydawnictwo Fundacji Humaniora.

Maruszewski, T., \& Ścigała, E. (1998b). Kłopotliwe uczucia. Charaktery, 5, pp. 12-16.

Matczak, A., Jaworowska, A., \& Stańczak, J. (2000). Rysunkowy Test Twórczego Myślenia K.K. Urbana i H.G. Jellena. TCT-DP. Podręcznik. Warszawa: Pracownia Testów Psychologicznych PTP.

Matczak, A., \& Knopp, K.A. (2013). Znaczenie inteligencji emocjonalnej w funkcjonowaniu człowieka. [Stare Kościeliska]: Liberi Libri.

Mayer, J.D., Perkins, D.M., Caruso, D.R., \& Salovey, P. (2001). Emotional intelligence and giftedness. Roeper Review, 23, pp. 131-137.

Mayer, J.D., Salovey, P., \& Caruso, D.R. (2000). Models of Emotional Intelligence. In: R.J. Sternberg (Ed.), Handbook of Intelligence (pp. 396-420). Cambridge, UK: Cambridge University. DOI: 10.1017/CBO9780511807947.019.

Mayer, J.D., Salovey, P., Caruso, D.R., \& Sitarenios, G. (2003). Measuring Emotional Intelligence with the MSCEIT V 2.0. Emotion, 3(1), pp. 97-105.

Nęcka, E. (2001). Psychologia twórczości. Gdańsk: GWP.

Nęcka, E. (2005). Psychologia twórczości. Gdańsk: GWP.

Nęcka, E. (2012) Psychologia twórczości. Sopot: GWP.

Popek, S. (1989). Kwestionariusz Twórczego Zachowania - KANH. Lublin: Wydawnictwo Uniwersytetu Marii Curie-Skłodowskiej.

Popek, S. (2003). Człowiek jako jednostka twórcza. Lublin: Wydawnictwo UMCS.

Popek, S. (2008). Kwestionariusz twórczego zachowania - KANH. Lublin: Wydawnictwo UMCS. 
Salovey, P., \& Mayer, J.D. (1990). Emotional Intelligence. Imagination, Cognition, and Personality, 9(3), 185-211. DOI: 10.2190/DUGG-P24E-52WK-6CDG.

Salovey, P., \& Sluyter, D.J. (Eds.) (1999). Rozwój emocjonalny a inteligencja emocjonalna. Problemy edukacyjne. Poznań: Dom Wydawniczy Rebis.

Śmieja, M., \& Orzechowski, J. (Eds.) (2008a). Inteligencja emocjonalna. Fakty, mity, kontrowersje. Warszawa: PWN.

Śmieja, M., \& Orzechowski, J. (2008b). Inteligencja emocjonalna w szkole. In: M. Śmieja, \& J. Orzechowski (Eds.), Inteligencja emocjonalna: fakty, mity, kontrowersje (pp. 39-41). Warszawa: PWN.

Sternberg, R.J. (1999). Wprowadzenie do psychologii. Warszawa: WSiP.

Szmidt, K.J. (1997). Elementarz twórczego życia. Warszawa: Wydawnictwo W.A.B.

Szmidt, K.J. (Ed.) (2009). Metody pedagogicznych badań nad twórczościq. Łódź: Wydawnictwo Akademii Humanistyczno-Ekonomicznej.

Szmidt, K.J. (2013). Pedagogika twórczości. Sopot: Gdańskie Wydawnictwo Psychologiczne.

Szmidt, K.J. (2017). Edukacyjne uwarunkowania rozwoju kreatywności. Łódź: Wydawnictwo Uniwersytetu Łódzkiego.

Tokarz, A. (2011). Procesy emocjonalne w aktywności twórczej. In: D. Doliński, \& W. Błaszczak (Eds.), Dynamika emocji. Teoria i praktyka (pp. 303-342). Warszawa: PWN.

Uszyńska-Jarmoc, J. (2007). Od twórczości potencjalnej do autokreacji w szkole. Białystok: Trans Humana. 